\title{
Research on the Current Situation and Countermeasures of Cross Border E-commerce Logistics
}

\author{
Jingxian Xu \\ TSL School of Business and Information Technology \\ Quanzhou Normal University \\ Quanzhou, China \\ yjsxjx@126.com
}

\author{
Yingfeng $\mathrm{Xu}^{*}$ \\ School of Marxism \\ Quanzhou Normal University \\ Quanzhou, China \\ xuyingfeng118@126.com
}

\begin{abstract}
At present, the development of cross-border ecommerce is very fast, but the cross-border e-commerce logistics development is very slow, which seriously affected the development of cross-border e-commerce, so it is necessary to study the factors restricting the development of cross-border ecommerce logistics. The purpose of this study is to identify the factors that influence the development of cross-border sub business logistics, and formulate development strategies based on these constraints. Through consulting a large number of documents, this study summarizes the current situation of crossborder e-commerce logistics, and summarizes the problems existing in cross-border e-commerce logistics. The conclusions are as follows: high logistics cost, unreasonable logistics system, insufficient supply of professionals and lack of logistics informatization. Our research shows that the Chinese government and cross-border e-commerce logistics enterprises adopt some corresponding strategies, they will break through the bottleneck of development. These strategies are as follows: through the establishment of strategic alliances to reduce logistics costs, increase the training of high-quality professional personnel, build cross-border logistics information system. This study provides a new way of thinking for the Chinese government and cross-border e-commerce logistics enterprises.
\end{abstract}

Keywords-Cross border e-commerce logistics; Present situation; Development Countermeasures; Overseas warehouse

\section{INTRODUCTION}

With the trend of the integration of the world economy and the globalization of China's e-commerce, cross-border ecommerce has become an important channel for foreign trade enterprises to expand overseas marketing [1]. Although China's cross-border e-commerce development is very fast, but crossborder e-commerce logistics development is relatively backward, therefore, logistics and distribution has become an important factor restricting China's cross-border e-commerce [2]. Compared with the developed countries, China's crossborder logistics costs are high, the time is slow, infrastructure and operation levels are lagging behind. These have not only restricted the rapid development of cross-border e-commerce in China, but also limited China's trade capacity. Logistics, as a bridge linking buyers and sellers, plays an important part in ecommerce transactions. Compared with the domestic e- commerce activities, cross-border e-commerce has the following characteristics: a large time span, space distance, wide range of coverage. Therefore, it is particularly important to realize the effective circulation of commodities in crossborder e-commerce and develop scientific and rational crossborder e-commerce logistics.

\section{DEVELOPMENT STATUS AND LOGISTICS MODE OF CROSS BORDER E-COMMERCE LOGISTICS}

\section{A. The development of cross border e-commerce in China}

According to China Electronic Commerce Research Center data statistics, China's cross-border e-commerce transactions reached 5 trillion and 400 billion in 2015, an increase of $28.6 \%$. Among them, the export of cross-border e-commerce transactions reached 4 trillion and 500 billion yuan, an increase of $26 \%$ [3]. In the first half of 2016, cross-border e-commerce transactions amounted to 2 trillion and 600 billion yuan, an increase of $30 \%$. Figure 1 shows the size of China's export cross-border e-commerce market transactions between 2012 and 2016. As can be seen from Figure 1, from 2012 to 2016, China's export cross-border e-commerce market transactions grew steadily. Figure 1 shows that China's cross-border ecommerce market transactions increased year by year, showing a rapid development trend. These data show that the future of cross-border e-commerce will become an irreplaceable trading model, with a broader market space.

According to China Electronic Commerce Research Center data statistics, China's cross-border e-commerce transactions reached 5 trillion and 400 billion in 2015, an increase of $28.6 \%$ [4]. Among them, the export of cross-border e-commerce transactions reached 4 trillion and 500 billion yuan, an increase of $26 \%$. In the first half of 2016, cross-border e-commerce transactions amounted to 2 trillion and 600 billion yuan, an increase of $30 \%$. Figure 1 shows the size of China's export cross-border e-commerce market transactions between 2012 and 2016. As can be seen from Figure 1, from 2012 to 2016, China's export cross-border e-commerce market transactions grew steadily. Figure 1 shows that China's cross-border ecommerce market transactions increased year by year, showing a rapid development trend. These data show that cross-border 
e-commerce will become an irreplaceable trading model, it has a broader market space.

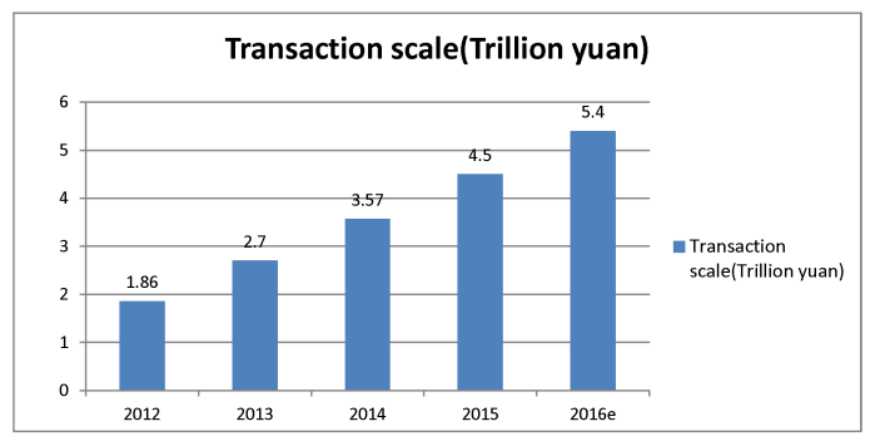

Fig. 1. 2012 - 2016 China export cross-border e-commerce market scale

\section{B. Logistics model of cross border e-commerce in China}

Parcel post model. This pattern covers the widest range. Parcels delivered by postal systems such as China Post, Hongkong post and Singapore Post account for about $70 \%$ of China's export cross-border e-commerce [5]. Postal parcel model has the advantages of low cost, but also has many shortcomings, such as parcel weight is strictly restricted, longer delivery time, easy to lose parcels.

International express mode. It is mainly provided by four international express delivery companies. It has many advantages, such as service delivery specialization, fast delivery speed and low packet loss rate, but there are some disadvantages, such as higher fees. And domestic express company transnational business starts late, its service system needs to be perfect.

\section{PROBLEMS IN CROSS-BORDER E-COMMERCE LOGISTICS}

Logistics distribution is a very important part of crossborder e-commerce [6]. At present, many cross-border logistics have appeared on the market, such as postal parcels and international express delivery, but the speed of cross-border ecommerce development still can not meet the growth needs of cross-border e-commerce. There are still many problems in cross-border e-commerce logistics, mainly in the following aspects:

\section{A. High logistics cost}

The high cost of logistics has been a difficult problem for China's cross-border e-commerce enterprises [7]. Figure 2 is the proportion of the total logistics cost of the whole society to GDP. As can be seen from the figure, in 2014, China's logistics costs accounted for $16.6 \%$ of the proportion of GDP. In 2015 , China's logistics costs accounted for $16 \%$ of GDP. These data show that the overall logistics cost of our society is gradually reduced. Although the cost of cross-border logistics has dropped faster in recent years, it is still about $9.5 \%$ higher than in developed countries, and it is about 5\% higher than the global average. From the above analysis, we can conclude that China's cross-border logistics costs are still relatively high.

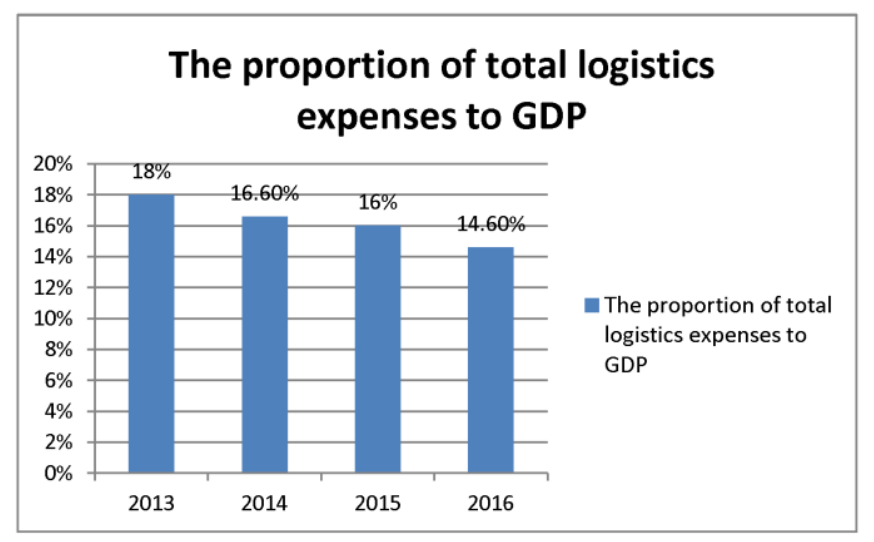

Fig. 2. 2013-2016, the proportion of the total logistics cost of the whole society is GDP

Most of China's cross-border e-commerce enterprises now choose the logistics model is express. Cross border logistics is more complicated, so the logistics cost is relatively high. The high cost of logistics reduces the advantages of Chinese goods in the international market competition, and also greatly affects the vigorous development of cross-border E-commerce.

\section{B. The logistics system is unreasonable}

The construction of cross-border logistics system is irrational, mainly reflected in the infrastructure construction of cross-border logistics is imperfect. In recent years, with the rapid development of cross-border e-commerce, a number of domestic logistics companies in a very short period of time to rapidly establish international logistics business. Because of the rapid development of international logistics business, it has caused many problems, such as inadequate infrastructure construction. These problems not only hinder the development of cross-border logistics industry, but also affect the development of other cross-border e-commerce industry.

\section{National policies and regulations are imperfect}

At present, some coastal cities in China have realized the information transmission between the customs and other departments and cross-border e-commerce enterprises. However, the development of service industry chain is still lagging behind, the complete supply chain system has not yet formed, and the corresponding laws and regulations and credit system are not perfect. These problems have hindered the development of cross-border e-commerce and logistics enterprises.

\section{The supply of professionals is inadequate}

Cross border e-commerce business is more complex than other e-commerce. Because cross-border e-commerce logistics is a comprehensive discipline, it needs to be proficient in crossborder e-commerce business, but also need to be proficient in cross-border logistics business. At present, many universities in China have set up e-commerce major and logistics major. It has trained a large number of e-commerce talents and logistics talents. Some universities have integrated e-commerce and logistics, but there is no school to integrate cross-border e- 
commerce and international logistics, these problems cause China's cross-border e-commerce talent is very scarce.

\section{E. The degree of logistics informatization is insufficient}

At present, most of the cross-border logistics use postal parcel model, which has the problem that logistics information can not be tracked in a timely manner. In the process of parcel delivery, customers can not get the goods logistics information in time. This situation is caused by asymmetric information between the two sides of the transaction, resulting in customer satisfaction and loyalty for cross-border e-commerce is not high. It's not just postal parcels. Some other international logistics companies are also unable to track the goods all the way. Secondly, cross-border logistics involves two countries. Because the level of informatization between the two two countries is different, this leads to the problem of the convergence of the logistics information system in the two countries.

Due to the high cost of information technology applications, cross-border e-commerce logistics services do not fully use advanced information technology, such as bar code inspection, electronic information, data exchange and geographic information systems. This situation leads to the problem that the lines of transportation are not optimal and the inventory control is poor. Cross border e-commerce logistics delivery does not apply information technology, eventually affecting customer satisfaction.

\section{COUNTERMEASURES FOR PROMOTING THE HEALTHY DEVELOPMENT OF CROSS BORDER E-COMMERCE LOGISTICS}

\section{A. Reduce logistics cost by establishing strategic alliance}

For cross-border e-commerce enterprises, independent self logistics will make the logistics costs of enterprises increase a lot. But if logistics cooperation between enterprises, the establishment of logistics strategic alliances between enterprises, which can greatly reduce the cost of logistics. The enterprise alliance builds a logistics storage center both at home and abroad. When the overseas buyer orders, the domestic distribution center delivers the goods to the overseas distribution center. Finally, foreign distribution centers distribute goods to buyers abroad.

\section{B. Improve the standard of logistics}

The standardization and standardization of cross-border ecommerce logistics can reduce the cost of logistics and improve the efficiency of logistics. In order to standardize the logistics standards of cross-border e-commerce, the national policy departments should seriously study the current laws of cross-border e-commerce logistics development. National policy departments can take some policies to promote standardization of construction, such as strengthening crossborder e-commerce enterprises and international logistics enterprises cooperation. We can also support cross-border ecommerce through financial support, tax incentives and other policies, and formulate laws and regulations conducive to the development of cross-border e-commerce logistics.

\section{Increase the training of high-quality professional personnel}

High quality cross-border e-commerce logistics professionals, not only have a solid English ability, but also to grasp foreign economic, trade, e-commerce and international logistics and other related knowledge and skills. To develop such a talent, first of all, colleges and universities should adjust the training direction and professional curriculum reform; secondly, to enhance the professional level of university teachers, colleges and universities can send some excellent teachers to go abroad to study cross-border e-commerce knowledge.

\section{Construction of cross border logistics information system}

At present, China's cross-border logistics lack of perfect information system support, and can not meet the rapid development of cross-border e-commerce needs. Therefore, the establishment of cross-border logistics information system to solve the problem of asymmetric information in cross-border logistics is extremely urgent. The Chinese government can coordinate the cross-border e-commerce enterprises, international logistics companies, customs and other parties to build cross-border logistics information system. On the basis of the existing customs information platform, the Chinese government can build a cross-border e-commerce public information platform. This platform can realize the electronic commerce enterprise and the physical distribution, between the third party payment organization interconnection and the data information resources sharing, also can satisfy the supervisory department's information demand.

Informatization is the reform direction of cross-border ecommerce logistics in china. The informatization of crossborder e-commerce logistics can reduce the rate of packet loss. The gradual improvement of cross-border e-commerce platform and logistics company can also improve the quality of logistics services. Cross border e-commerce logistics enterprises should build intelligent logistics database, which can intelligently analyze the user's demand, so the Intelligent Logistics database can reduce inventory costs. This database not only automatically generates the date of shipment and the quantity of goods needed, but also solves the problem of overstock of warehouses in overseas warehouses. Therefore, the informatization of logistics and the construction of Intelligent Logistics database can improve consumer satisfaction.

\section{SUMMARY}

At present, the development of cross-border e-commerce is very fast, and it puts forward high requirements for the trading platform, payment and settlement, customs, commodity inspection, logistics, storage, transportation and other aspects. However, the existing logistics service system can not meet the needs of cross-border e-commerce development. Through the survey found that there are many factors affecting the development of cross-border e-commerce, in-depth analysis of these factors, our research shows that national and cross-border e-commerce logistics enterprises to take corresponding measures, can solve the existing problems in the development 
of cross-border e-commerce. These strategies can provide some ideas for the development of cross-border e-commerce logistics enterprises, and the implementation of these strategies can break through the bottleneck of cross-border e-commerce business development.

\section{ACKNOWLEDGMENT}

This work was financially supported by:

(1) Fujian Natural Science Foundation of China (Number 2015J01286): Research on e-commerce chain based on Collaborative Perspective in cloud computing environment.

(2) JK project of Fujian Provincial Department of Education (Number JK2014037): Research on e-commerce chain coordination based on Cloud Computing.

(3) Curriculum Construction Project of Quanzhou Normal University: Demonstration Network Course Construction--ERP (Enterprise resource planning).

(4) Students Innovation and Entrepreneurship Training Program Funded Projects of Quanzhou Normal University.

(5) Fujian Province young and middle-aged teacher education research project (Number JAT170494): Research on university teaching resource sharing based on Cloud Computing.

(6) The Teaching Reform Foundation Research Funds of School of Marxism, Quanzhou Normal University (2017).
(7) Fujian Province young and middle-aged teacher education research project (Number JAS170399): Xi Jinping's thought of ecological poverty alleviation and its practical significance for the development of Fujian.

\section{REFERENCES}

[1] Riccardo Mangiaracina,Gino Marchet,Sara Perotti,Angela Tumino, A review of the environmental implications of B2C e-commerce: a logistics perspective, International Journal of Physical Distribution \& Logistics Management, 2015, pp. 565-591.

[2] Fan Jing, Yuan Bin, Experience and Enlightenment of cross-border ecommerce logistics model innovation in foreign countries, Commercial economy research, 2016, pp. 133-135 (In Chinese).

[3] Lin Fang, Analysis and Discussion on innovation ways of cross border e-commerce logistics mode, Logistics engineering and management, 2016, pp. 107-108 (In Chinese).

[4] Mangiaracina,Alessandro Perego,Angela Tumino, Cross-border B2C ecommerce to Greater China and the role of logistics: a literature review, International Journal of Physical Distribution \& Logistics Management, 2017, pp. 772-795.

[5] Feng Na, Discussion on the current situation and operation mode of cross border e-commerce logistics in China, National business, 2016, pp. 9-10 (In Chinese).

[6] Rao Qiaomei, Analysis of innovation and development trend of cross border e-commerce logistics mode, Chinese Market, 2016 ,pp. 123-124 (In Chinese).

[7] Du Junpeng, Discussion on the current situation and operation mode of cross border e-commerce logistics in China, Shopping mall modernization, 2016 ,pp. 45-46 (In Chinese). 